ornl

OAK RIDGE NATIONAL LABORATORY

MARTIN MARUETRA
ORNL/ATD-63

FIBERGLASS MATERIAL SPECIFICATION III -.

B. J. Frame

October 1991

MANAGED BY

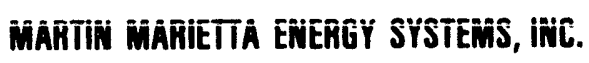

FOR THE UNITED STATES

DEPARTMENT OF ENERGY 
This report has been reproduced directly from the beat available copy.

Avallable to DOE and DOE contractors from the Otfice of Scientific and Tectnical Information, P.O. Box 62, Oak Ridoo, TN 37831: prices availablo from (615) 576-8401, FTS 623-840i.

This report was prepared as an account of work sponsored by an agency of the United States Government. Neither the United States Government nor any agency thereof, nor any of their employees, makes any wartanty, express or implied, or assumes any legal liability or responsibility for the accuracy, completenese, or usefunnese of any information, apparatus, product, or process disclosed, or represents that its use would not intringe privately owned rights. Reference herein to any specific commercial product, process, or senvice by trade name, trademark, manufacturer, or otherwise, does not necessarity constttute or imply its endorsernent, recommendation, or favoring by the United States Government or any egency thereot. The views and opinions of authors expressed herein do not necessearily state or reflect those of the United States Government or any agency thereot. 
ORNL/ATD -63

DE92 005313

Applied Technology Division

FIBERGLASS MATERIAL SPECIFICATION III

B. J. Frame

C. J. Janke

Date Published-October 1991

Prepared by the

Oak Ridge National Laboratory

Oak Ridge, Tennessee 37831-7294

managed by

MARTIN MARIETTA ENERGY SYSTEMS, INC.

for the

U.S. DEPARTMENT OF ENERGY under contract DE-AC05-84OR21400 


\section{FIBERGLASS MATERIAL SPECIFICATION}

\subsection{SCOPE}

This specification describes the requirements for composite parts to be furnished to Martin Marietta Energy Systems, Inc., hereinafter referred to as the Company.

\subsection{APPLICABLE DOCUMENTS}

MIL-P-9400B

HMS 20-04.16, Revision C

M2E800618A164

\subsection{PART FABRICATION REQUIREMENTS}

Prior to fabrication of the composite parts the Seller (subcontractor) shall furnish to the Company, for review, a process specification that shall conform in content and format to MIL-P-9400B, 26 April 1977, with regard to identification of materials and processing equipment, description of raw material preparation, lay-up, and fabrication procedures. For purposes of this procurement, the requirements of MIL-P-9400B shall be modified as needed to incorporate the following requirements (the section and paragraph numbers refer to MIL-P-9400B).

1. All prepreg material used in the fabrication of the composite parts and test specimens shall be a toughened, epoxy resin impregnated E-glass fabric having mechanical and physical properties conforming to the Hitco Material Specification (HMS) 20-04.16, Revision C, Class I Materials. In addition, only those Class I Materials appearing on the Qualified Products List (QPL) that are referenced in HMS 20-04.16 shall be used in the manufacture of these parts and test specimens. The prepreg materials and their corresponding suppliers on the QPL are given here.

\section{SUPPLIER PRODUCT DESIGNATION}

7781-Z6040/E719 LT 1582-Z6040/E719 LT 1583-Z6040/E719 LT

\section{SUPPLIER}

BP Chemicals (HITCO), Inc. 700 East Dyer Road Santa Ana, CA 92705 (714) $549-1101$ 
CYCOM 5920-7781

CYCOM 5920-1582

CYCOM 5920-1583

MXB 7780/7781

MXB 7780/1582

MXB 7780/1583
American Cyanamid

21444 Golden Triangle Road

Saugus, CA 91350

(213) 625-0421

ICI Fiberite Composite Materials

645 North Cypress

Orange, CA 92666

(714) 639-2050

NOTE: The finish on these glass fabrics shall be $\mathrm{Z} 6040$.

2. Section 3.4.1.2. All parts shall be Type I, plastic laminate, manufactured by the dry lay-up method.

3. Paragraph 3.4.1.2.2. The following additional requirement shall apply: "Prepreg cutting methods shall be defined and shall not have any degrading effects on material properties."

4. Paragraph 3.4.1.5. Trimming and finishing of the completed parts will be the responsibility of the Seller.

5. Paragraph 3.5. The following are allowable and repairable defects. Defects which are beyond the limits shown will require Company approval prior to repair.

Voids. Voids shall be less than $3 \%$ maximum by volume and uniformly dispersed. The maximun. allowable void size shall be less than $1 / 4 \mathrm{in}^{2}$.

Overlaps \& Gaps. No overlaps are allowed between side-by-side plies, and all joints siiall be butt joints. Gaps that exist between side-by-side plies in butt joints shall be no larger than $1 / 16$ in.

Cracks. No cracks or fractures are allowed.

Surface Defects. Surface defects, including blisters, holes, chips, gouges, scratches, etc., shall not have a maximum depth greater than 0.02 in. from the surfaces of the part. For surface defects that have depths exceeding these limits, repair procedures shall be written by the Seller and submitted to the Company for approval prior to repair of any surface defect.

Resin Starvation. None allowed.

Wrinkles, Resin Ridges, Raised Areas, etc. All reasonable measures will be taken to minimize wrinkles and folds in the prepreg during lay-up and cure of the part. Wrinkles, folds, resin ridges, raised areas, etc., exceeding 0.010 in. are not permitted on the surfaces of the part. For surface wrinkles, resin ridges, raised ridges, etc., exceeding this limit, repair procedures shall be prepared by the Seller and submitted to the Company for approval prior to repair of these defects. 
Delaminations. Delaminations shall not be allowed.

Foreign Matter. Not acceptable. Procedures for removing foreign matter and repair of the part shall be prepared by the Seller and submitted to the Company for approval prior to beginning the repair procedure.

6. Paragraph 3.6.1. The minimum test requirements shall be as specified and defined in this material specification document.

7. Paragraph 3.7. There are no applicable electrical requirements.

8. Paragraph 4.5.2. First part inspection shall be as specified and defined in this material specification document.

9. Paragraph 4.7. Final dimensional and nondestructive testing (NDT) inspections for each manufactured part shall be fully described and performed by the Seller.

10. All parts shall be fabricated in accordance with the company drawings and with a $\left[0^{\circ} \pm 45^{\circ} / 90^{\circ}\right]_{\mathrm{n}}$ quasi-isotropic lay-up.

11. The laminate shall be a $\left[0^{\circ} \% 45^{\circ} / 90^{\circ}\right]_{\mathrm{n}}$ quasi-isotropic laminate that has the minimum B-basis mechanical and physical properties listed in Table 1. For first part fabrication, these properties shall be verified by test on specimens taken from a panel laid-up and cured in the same manner as and concurrent with the part. Each panel shall be tested for void content and fiber content by the Seller or a Company-approved independent testing laboratory. NOTE: If an independent testing laboratory is to be used, the seller shall provide a listing of proposed laboratories with the offer. With the exception of void content and fiber content, all mechanical property testing shall be performed by an independent testing laboratory that has been approved by the Company prior to the shipment of the test specimens by the Seller. Only those tests shown with an asterisk $\left({ }^{*}\right)$ need be performed on subsequent fabrication of identical parts. Specimen preparation and mechanical testing shall be performed on $\left[0^{\circ} / \pm 45^{\circ} / 90^{\circ}\right]_{n}$ laminates. The test temperature for all testing shall be $75 \pm 10^{\circ} \mathrm{F}$.

The Seller (or Company-approved independent testing laboratory) shall determine the void content and fiber content for each manufactured part. All testing results obtained by the Seller and the independent testing laboratory shall be submitted to the Company prior to shipment of each part. (Subsequent changes to the material supplier or process specification require reinstatement of first part testing requirements. Note that destructive testing of the first part is not necessarily required.) 
Table 1. The $\left[0^{\circ} / \pm 45^{\circ} 190^{\circ}\right]$, laminate properties

* Maximum void content (\%) - required for each panel and each part . . . . . 3.0

* Minimum fiber content (\% by wt) - required for each panel and each part . 60.0

WET CONDITION (72-hour water boil)

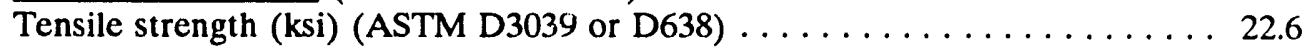

Tensile modulus (msi) (ASTM D3039 or D638) $\ldots \ldots \ldots \ldots \ldots \ldots \ldots .96$

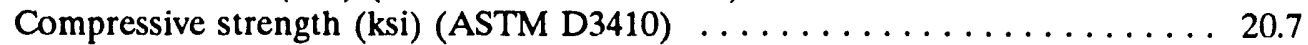

In-plane shear strength (ksi) (Iosipescu Method or ASTM D4255) . . . . . 11.5

In-plane shear modulus (msi) (Iosipescu Method or ASTM D4255) $\ldots \ldots \ldots 0.72$

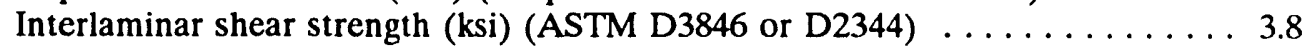

Bearing strength (ksi) (ASTM D953 - Procedure A, Type II) . . . . . . . 44.0

DRY CONDITION (as is)

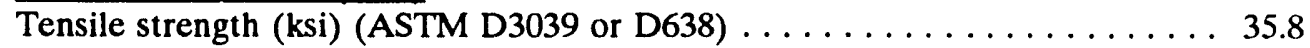

Tensile modulus (msi) (ASTM D3039 or D638) $\ldots \ldots \ldots \ldots \ldots \ldots \ldots .47$

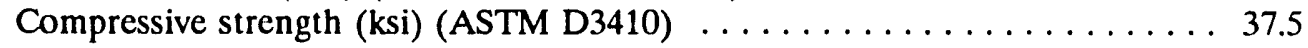

In-plane shear strength (ksi) (Iosipescu Method or ASTM D425i) . . . . . 19.8

In-plane shear modulus (msi) (Iosipescu Method or ASTM D4255) . . . . 0.96

${ }^{*}$ Interlaminar shear strength (ksi) (ASTM D3846 or D2344) $\ldots \ldots \ldots \ldots 6.5$

*Tests must be performed on subsequent fabrication of identical parts.

12. All tooling specific to the fabrication of the parts becomes the property of the Company at the completion of the subcontract.

13. The Seller shall package and ship parts in a manner affording sufficient protection so as not to damage the parts during transit.

14. At the time of delivery, the Seller shall furnish the following quality documentation:

a. Manufacturer's certification documents for all materials used directly in the part.

b. Inspection and final test reports for all inspections and tests performed by the Seller. 


\section{Internal Distribution}

T. R. Bu+ler

C. P. Chihasz

B. J. Frame (15)

C. J. Janke

L. G. Kauffman

W. A. Miller

E. D. Needham

R. E. Norris

D. A. Waters

R. E. Ziegler

Laboratory Records - RC

Department of Energy, Oak Ridge Field Office

Assistant Manager, Energy Research and Development

\section{External Distribution}

Office of Scientific and Technical Information (2)

P.O. Box 62, Oak Ridge, TN 37831 


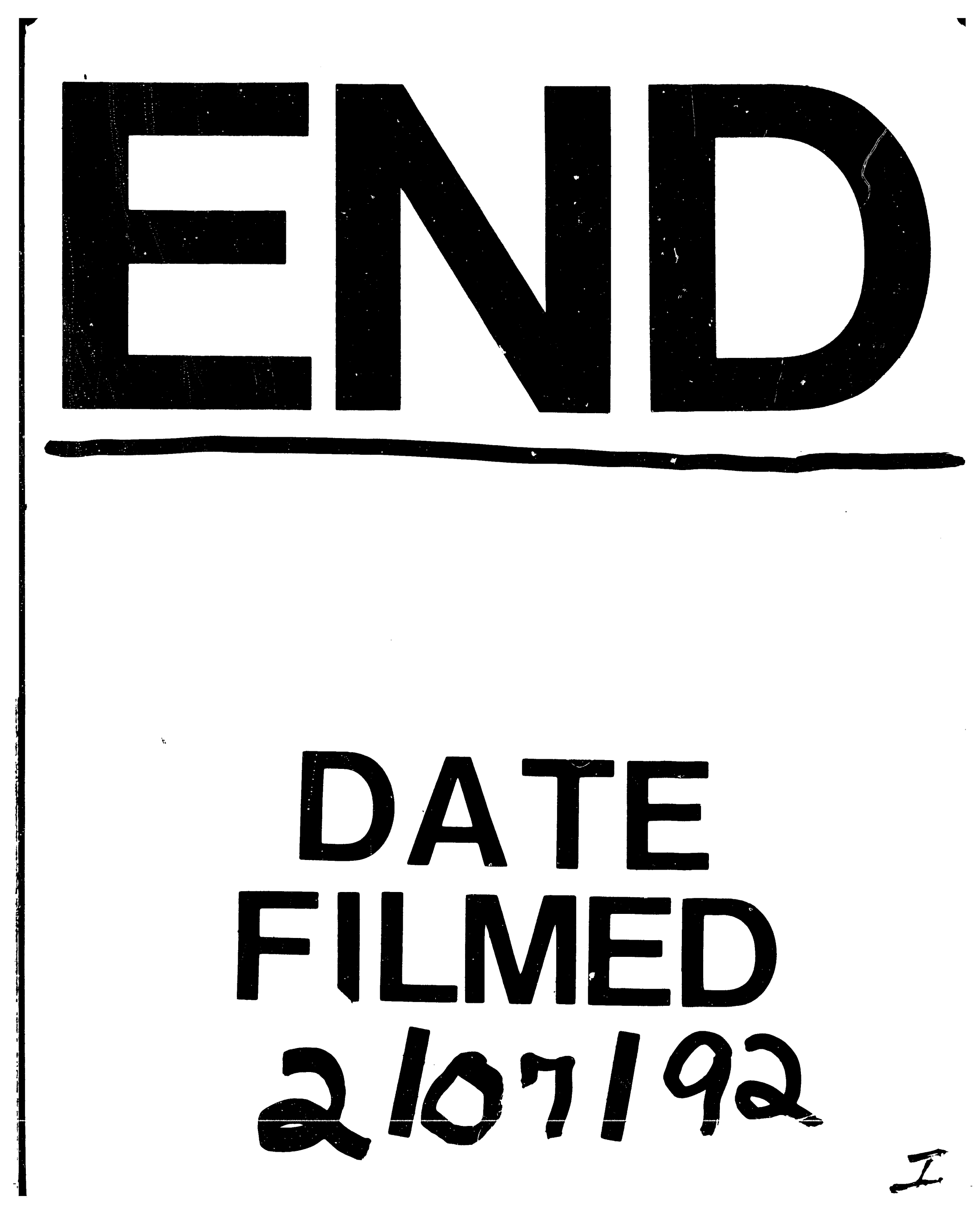


